\title{
A SOCIO-MEDICAL STUDY OF HAEMOPHILIA AND RELATED STATES
}

\author{
BY \\ I. G. BRONKS, M.B., M.R.C.P. (ED.), D.P.M.
}

AND

E. K. BLACKBURN, M.D., F.R.C.P. (Glasg.), F. C. Path., D. Obst., R.C.O.G., M.I.NuC.E.

From the University Department of Psychiatry and the Department of Haematology, The Royal Infirmary, Sheffield

Haemophilia is a chronic haemorrhagic disease due to deficiency of plasma antihaemophilic globulin (factor VIII). It is classically inherited in sex-linked recessive fashion, being transmitted from carrier mother to son. However, there is no family history in about one-third of haemophilics. The incidence of the disorder in England is thought to be about three or four per 100,000 of population, while Christmas disease, inherited similarly, and with similar clinical manifestations but due to deficiency of factor IX, is about one-tenth as common. A relatively small number of patients with hereditary capillary defects also show deficiency of factor VIII and much more rarely of factors IX or XI, the coagulation defects being usually of mild degree.

While much has been written about organic clinical problems in haemophilia, we found that far fewer studies of the social, psychological, and psychiatric aspects appeared to have been made. In 1964 we decided to follow up the patients suffering from deficiency of factor VIII or factor IX who had been referred to the Department of Haematology in the previous decade, excluding those known to have left England or died. A questionnaire was designed and forwarded to the patient's general practitioner for his approval. With the general practitioner's consent, the questionnaire was then mailed with a covering letter to the patient (or, if a child, to his parent or guardian) for completion and return. The questionnaire enquired among other things about the patient's social and educational background, work record, medical and psychiatric history, and his views on the influence of psychological stress on his tendency to bleed. The majority of the data asked for were factual.

Each patient had previously been placed in one of three clinical categories as follows:
(1) Severe.-Abnormal bleeding, sometimes apparently spontaneous, including bruising, haemar- $ᄋ$ throses, muscle haemorrhages, and bleeding from mucosal surfaces. Gross bleeding after minor trauma.

(2) Moderately Severe.-Bruising abnormally easily but less than in the severe group. Severe $\vec{\varnothing}$ bleeding after minor injury and after surgical opera tions. No haemarthroses or muscle haemorrhages except after appreciable trauma.

(3) Mild.-Excessive haemorrhage after major injuries or operations. Sometimes a tendency to bruising abnormally easily but less than in (2). No bleeding into joints and muscles except after severe trauma.

The results of laboratory tests, including wholeblood clotting time, thromboplastin generation test with suitable dilution and cross correction tests, and more latterly specific assays of factors VIII and IX, were compatible with the three clinical groups.

Of 177 patients who received the questionnaire, 135 (76 per cent.) replied. The sex and diagnostic distribution are shown in Table I.

TABLE I

DISTRIBUTION OF 135 CASES BY SEX AND DIAGNOSIS

\begin{tabular}{|c|c|c|c|}
\hline Deficiency & Male & Female & Total \\
\hline Factor VIII .. & 111 & 10 & 121 \\
\hline Factor IX $\quad \ldots$ & 12 & 2 & 14 \\
\hline Total & 123 & 12 & 135 \\
\hline
\end{tabular}

As the numbers of females and of patients with factor IX deficiency are too small for separate? statistical analysis, all the patients have been con- $T$ sidered as a single group under the designation "haemophilia". 
SEVERITY OF ILLNESS

The severity of the haemorrhagic tendency as defined above is shown in Table II.

TABLE II

SEVERITY OF HAEMORRHAGIC TENDENCY IN 135 CASES

\begin{tabular}{c|c}
\hline Severity & No. of Patients \\
\hline Mild & 44 \\
\hline Moderate & 21 \\
\hline Severe & 70 \\
\hline Total & 135 \\
\hline
\end{tabular}

Age Distribution (Table III)

As expected, our patients were much younger as a group than the general population. However, the number surviving beyond the early thirties is notable. Seventeen of these 33 patients had severe disease and all were born well before the advent of modern methods of treatment.

TABLE III

AGE DISTRIBUTION OF HAEMOPHILICS COMPARED WITH

\begin{tabular}{c|c|c|c}
\multicolumn{2}{|c|}{ THE GENERAL POPULATION } \\
\hline \multirow{2}{*}{ Age Group (yrs) } & \multicolumn{2}{|c|}{ Hámophilics } & $\begin{array}{c}\text { General } \\
\text { Population } \\
\text { (1961 Census) }\end{array}$ \\
\cline { 2 - 3 } & No. & Per cent. & Per cent. \\
\hline $0-14$ & 44 & $32 \cdot 6$ & $23 \cdot 0$ \\
$15-24$ & 37 & 27.4 & 13.2 \\
$25-34$ & 21 & $15 \cdot 6$ & 12.6 \\
$35-44$ & 20 & $14 \cdot 8$ & 13.6 \\
$45-54$ & 9 & $6 \cdot 7$ & $14 \cdot 0$ \\
$55-64$ & 3 & $2 \cdot 2$ & $11 \cdot 7$ \\
$65+$ & 1 & 0.7 & $11 \cdot 9$ \\
\hline Total & 135 & 100 & 100 \\
\hline
\end{tabular}

Education (Tables IV and V)

Only three patients did not attend school after the age of 11. The school-leaving age appears to compare favourably with that of the general population even allowing for the difference in age distribution.

\section{TABLE IV}

TYPE OF SCHOOL ATTENDED AFTER AGE 11

\begin{tabular}{l|r|r}
\hline \multirow{2}{*}{ Type of School } & \multicolumn{2}{|c}{ Haemophilics } \\
\cline { 2 - 3 } & No. & Per cent. \\
\hline Secondary Modern & 60 & $57 \cdot 1$ \\
Grammar & 18 & $17 \cdot 1$ \\
Technical & 3 & $2 \cdot 9$ \\
Comprehensive & 2 & $1 \cdot 9$ \\
Public School & 6 & $5 \cdot 7$ \\
Other & 13 & $12 \cdot 4$ \\
None & 3 & $2 \cdot 9$ \\
\hline Total & 105 & 100 \\
\hline
\end{tabular}

TABLE V

AGE ON COMPLETING FULL-TIME EDUCATION

\begin{tabular}{c|r|r|r}
\hline \multirow{2}{*}{ Age Group (yrs) } & \multicolumn{2}{|c|}{ Haemophilics } & $\begin{array}{c}\text { General Population } \\
\text { (1961 Census) }\end{array}$ \\
\cline { 2 - 4 } & No. & Per cent. & Per cent. \\
\hline Under 13 & 2 & $2 \cdot 4$ & $2 \cdot 8$ \\
13 & 4 & $4 \cdot 8$ & $6 \cdot 9$ \\
14 & 20 & $23 \cdot 8$ & $49 \cdot 1$ \\
15 & 39 & $46 \cdot 4$ & $19 \cdot 7$ \\
16 & 13 & $15 \cdot 5$ & $9 \cdot 3$ \\
17 & 4 & $4 \cdot 8$ & $3 \cdot 6$ \\
$18+$ & 2 & $2 \cdot 4$ & $8 \cdot 6$ \\
\hline Total & 84 & $100 \cdot 1$ & 100 \\
\hline
\end{tabular}

Occupational Record (Tables VI and VII)

More than three-quarters of the 87 patients who had left school were working at the time of the

TABLE VI

EMPLOYMENT STATUS OF 87 PATIENTS AT TIME OF SURVEY, BY GRADE OF HAEMOPHILIA

\begin{tabular}{|c|c|c|c|c|c|c|c|c|}
\hline \multirow{3}{*}{ Employment } & \multicolumn{6}{|c|}{ Degree of Haemophilia } & & \\
\hline & \multicolumn{2}{|c|}{ Mild } & \multicolumn{2}{|c|}{ Moderate } & \multicolumn{2}{|c|}{ Severe } & \multicolumn{2}{|c|}{ Total } \\
\hline & No. & Per cent. & No. & Per cent. & No. & Per cent. & No. & Per cent. \\
\hline $\begin{array}{l}\text { Employed } \\
\text { Not Employed } \\
\text { Retired . } \\
\text { At University }\end{array}$ & $\begin{array}{r}29 \\
1 \\
0 \\
1\end{array}$ & $\begin{array}{r}93 \cdot 6 \\
3 \cdot 2 \\
\frac{1}{3 \cdot 2}\end{array}$ & $\begin{array}{r}12 \\
3 \\
1 \\
0\end{array}$ & $\begin{array}{r}75 \cdot 0 \\
18 \cdot 8 \\
6 \cdot 2 \\
-\end{array}$ & $\begin{array}{r}26 \\
14 \\
0 \\
0\end{array}$ & $\begin{array}{l}65 \cdot 0 \\
35.0 \\
=\end{array}$ & $\begin{array}{r}67 \\
18 \\
1 \\
1\end{array}$ & $\begin{array}{r}77 \cdot 0 \\
20 \cdot 7 \\
1 \cdot 2 \\
1 \cdot 2\end{array}$ \\
\hline Total $\quad$. & 31 & 100 & 16 & 100 & 40 & 100 & 87 & 100 \\
\hline
\end{tabular}

TABLE VII

OCCUPATIONAL RECORD OF 87 CASES DURING PREVIOUS 5 YEARS, BY GRADE OF HAEMOPHILIA

\begin{tabular}{|c|c|c|c|c|c|c|c|c|}
\hline \multirow{3}{*}{$\begin{array}{l}\text { Proportion } \\
\text { worked in } \\
\text { past } 5 \text { yrs } \\
\text { (per cent.) }\end{array}$} & \multicolumn{6}{|c|}{ Degree of Haemophilia } & & \\
\hline & \multicolumn{2}{|c|}{ Mild } & \multicolumn{2}{|c|}{ Moderate } & \multicolumn{2}{|c|}{ Severe } & \multicolumn{2}{|c|}{ Total } \\
\hline & No. & Per cent. & No. & Per cent. & No. & Per cent. & No. & Per cent. \\
\hline $\begin{array}{c}0-60 \\
60-80 \\
80-100 \\
\text { Other }\end{array}$ & $\begin{array}{r}0 \\
2 \\
28 \\
1\end{array}$ & $\begin{array}{r}\overline{6 \cdot 4} \\
90 \cdot 4 \\
3 \cdot 2\end{array}$ & $\begin{array}{r}0 \\
3 \\
11 \\
2\end{array}$ & $\begin{array}{l}\overline{18 \cdot 7} \\
68 \cdot 8 \\
12 \cdot 5\end{array}$ & $\begin{array}{r}17 \\
8 \\
15 \\
0\end{array}$ & $\begin{array}{l}42 \cdot 5 \\
20 \cdot 0 \\
37 \cdot 5 \\
-\end{array}$ & $\begin{array}{r}17 \\
13 \\
54 \\
3\end{array}$ & $\begin{array}{r}19 \cdot 6 \\
14 \cdot 9 \\
62 \cdot 1 \\
3 \cdot 4\end{array}$ \\
\hline Total & 31 & 100 & 16 & 100 & 40 & 100 & 87 & 100 \\
\hline
\end{tabular}


survey. Amongst the clinically severe group, 65 per cent. were at work, and more than half of them had been at work for over 60 per cent. of the preceding 5 years. The records of patients with less severe illness were correspondingly better.

Psychiatric History and Effect of Psychological Stress (Table VIII)

Nine patients $(6.7$ per cent.) stated that they had seen a psychiatrist. Further enquiry disclosed that only six had in fact received psychiatric treatment. The psychiatric diagnoses in these six cases were as follows: schizophrenia (2), depression (2), anxiety neurosis (1), drug addiction to analgesics prescribed for painful haemarthroses (1).

TABLE VIII

PATIENT'S VIEW ON EFFECT OF PSYCHOLOGICAL STRESS ON HAEMORRHAGIC SYMPTOMS

\begin{tabular}{c|c|c|c}
\hline Age (yrs) & Yes & No & Don't Know \\
\hline $0-14$ & 33 & 12 & 29 \\
$15+$ & 34 & 29 & 28 \\
\hline
\end{tabular}

$\left(\chi^{2}=19 \cdot 1 ;\right.$ d.f. $\left.2 ; P<0.001\right)$.

To the question "Do you have more trouble from bruising and/or other bleeding troubles when you are worried or anxious ?", 37 patients (27.4 per cent.) replied "Yes", 41 (30.4 per cent.) replied "No", and $57(42 \cdot 2$ per cent.) replied "Don't know". Significantly more of the younger patients replied "No" or "Don't know".

The patients' opinions of the effect of psychological stress were unrelated to the different grades of severity.

\section{Marital Status}

Of 85 patients of marriageable age, $42(49.4$ per cent.), 38 males and 4 females, were or had been married. Thirty of these patients had had a total of 57 children. Unexpectedly, there were no significant differences between the different grades of severity either in the proportion married or in the number of children.

\section{Social Circumstances}

129 patients (95.6 per cent.) were living with their families or close relatives, four ( 3.0 per cent.) were living alone in lodgings or flats, and two (1.5 per cent.) were away at Residential Schools.

\section{OTHER FACTORS}

The items in the questionnaire relating to examinations passed when at school, further education, and health record did not appear to yield significant further information. These results are not presented here.

\section{Discussion}

The social and occupational handicaps caused by 3 haemophilia, particularly in its severer forms, are widely known and have been well described by Katz $(1959,1963,1964)$. The possible psychiatric implications have been less well studied and the literature contains relatively few references to this aspect.

\section{Social Aspects}

The vast majority of our patients have been or are being educated at ordinary schools. Only three did not attend school at all after the age of 11 and only eleven had attended special schools for the physically handicapped. This contrasts with the finding of Britten, Spooner, Dormandy, and Biggs (1966) that, of 150 haemophilic children aged 11 or more, seventy (47 per cent.) were attending schools for the physically handicapped (including open-air and hospital schools) or were receiving home tuition.It may $\infty$ reflect greater availability of these facilities, or greater emphasis on their use by doctors and educationists in the areas covered by their survey, compared with the Midlands and North. Selection does not account for the difference because the severity of disease in non-responders to the questionnaire was not signifi cantly different from that of the responders. We did not assess the extent to which haemophilics were handicapped at the schools they actually attended Hence our results do not provide evidence whether or not a new boarding-school for haemophilics should be established, as has been suggested.

In the mildly and moderately affected grades, the occupational record of our patients was excellent. Only amongst the severe group were there any who had been at work for less than 60 per cent. of the previous 5 years. Even among this group more than half had been working at least 60 per cent. of the time. 77 per cent. of the patients (65 per cent. of the severe group) were working at the time of the survey. Bearing in mind the severe physical handicaps of some of these patients and the need in many cases for repeated hospitalization, we believe that these results are very satisfactory. They bear witness to the determination of patients to succeed in the face of prolonged adversity and to the efforts of many workers in the treatment and rehabilitation fields. Katz $(1959,1963)$ found that 555 (71 per cent.) of 776 haemophilics who had left school were working at the time of his survey, a figure comparable to our own.

A high proportion of haemophilics marry and have children; 42 (49.4 per cent.) of 85 patients of $\stackrel{\oplus}{?}$ marriageable age were, or had been, married, a 0 figure almost identical to the 48.9 per cent. found by Katz (1963). This total is, however, significantly 
lower than that for the general population (1961 census), allowing for the difference in age distribution $\left(\chi^{2}=4.2\right.$; d.f. $\left.1 ; \mathrm{P}<0.05\right)$.

Only six patients were living in any circumstances other than with their families, and of these only four ( 3.0 per cent.) were living alone. A stable and supportive home environment is clearly important in enabling the haemophilic to overcome his handicaps, to avoid hazardous physical activities, and to obtain treatment quickly when necessary. For example, two of our patients experienced delay in obtaining necessary transfusion treatment because they were living alone. These figures also tend to support the view that serious personality disturbances, which lead to social isolation, are not unduly frequent in haemophilics.

\section{Psychological AsPects}

A continuous life-threatening situation, present from infancy and persisting throughout life might be expected to present a considerable psychological stress, possibly leading to overt psychiatric illness, or precipitating this in those vulnerable for other reasons. Agle (1964a, b) studied sixteen bleeders, claiming that psychiatric syndromes were often seen and were in some cases directly related to the emotional effects of the bleeding disorder. His patients included eight with anxiety states and recurrent depressions. Nine patients described recurrent risk-taking behaviour of significant degree, related by Agle in all cases to maternal overprotection. Poinsard (1957) studied 25 bleeders, using psychiatric interviews and psychological tests. He concluded that the prevailing emotional pattern was either one of passive dependency or hostility and aggression together with tension and anxiety. He found no correlation between emotional adjustment and severity of haemophilia, but gives no figures to support his conclusions. Browne, Mally, and Kane (1960) studied 28 haemophilic children and presented anecdotal evidence suggesting that emotional factors can contribute to the timing of spontaneous bleeding episodes in haemophilia. Lack of controls and the impossibility of knowing what the patients' emotional adjustment and behaviour would have been had they not been haemophilic are noted.

Six ( 4.5 per cent.) of our patients had received psychiatric treatment at some time. The comparable figure for the general population is not known with accuracy, but seems unlikely to be significantly less than this. In so far as the proportion who have had psychiatric treatment is a measure of the prevalence of emotional ill-health in a community (and the limitations are obvious) our figures suggest that evidence from uncontrolled investigations that haemophilia is a direct cause of psychiatric disorder must be taken with reserve. Certainly the presence of two schizophrenics, two depressives, one anxiety neurotic, and one drug addict in a population of 135 , even a relatively young one, would not strike one as significantly different from the norm. The failure of our enquiry to establish that haemophilia is liable to cause marked psychiatric symptoms might be attributed to the shortcomings of the questionnaire, which did not attempt to explore the patients' mental state in any detail. It is nevertheless remarkable how little the patients' mode of life differed from that of the general population, and it could be argued that, if there had been serious neurotic and other symptoms, this could not have been without effect on the patients' work record and way of life.

Four of the psychiatric patients were among the ten with a work record of less than 10 per cent. in the previous 5 years, in keeping with the well-known observation that psychiatric problems are particularly prevalent in those who present the greatest difficulties in rehabilitation.

The fact that $37(27.4$ per cent.) of the patients thought that their bleeding was made worse by worry and anxiety would support the suggestion of Poinsard (1957), Browne and others (1960), and Agle (1964a, b) that bleeding episodes can be induced by emotional factors, but this is a field in which it is hard to obtain evidence which is other than anecdotal. Hollán, István, and Feszler (1966) amongst others, have suggested that emotional stress precipitates or worsens bleeding episodes by increased fibrinolysis. The fact that the answers "No" and "Don't Know" were significantly more frequent in the replies from younger patients, whose questionnaires were completed by their parents, suggests that parents may tend to deny or to be unaware of anxieties in their haemophilic children.

\section{SUMMARY}

(1) A questionnaire relating to social, psychological and psychiatric aspects of the disease, was sent to 177 haemophilic patients who had been referred over a decade and who were deficient in factors VIII or IX; 135 replies were received.

(2) Haematologically, seventy patients were severely affected, 21 moderately, and 44 mildly so. Seventeen of the 33 patients over the age of 35 years were severely affected. Only three of the 105 patients over the age of $11 \mathrm{had}$ not attended school and only eleven had attended special schools. The 
school-leaving age compared favourably with that in the general population.

(3) The occupational record of the mildly and moderately affected patients was excellent. More than half of the severely affected patients had been working for at least 60 per cent. of the previous 5 years, while at the time of the survey 65 per cent. of them were working.

(4) There were no significant differences between the different grades of severity either in the proportion of married patients or in the numbers of their children. Fewer haemophilics married compared with the general population.

(5) 129 patients were living with their families or close relatives.

(6) 37 patients thought that emotional stress exaggerated bleeding episodes, while 41 did not hold this view and 57 did not commit themselves either way.

(7) Only six of the patients had received psychiatric treatment. This enquiry failed to confirm that haemophilia is liable to cause marked psychiatric symptoms.

We are indebted to Prof. E. Stengel for his continued advice and enthusiasm. Our thanks are also due to Dr J. Carson for his help in the formulation of this project.

\section{REFERENCES}

Agle, D. P. (1964a) Arch. intern. Med., 114, 76 (Psychiatric 3 studies of patients with hemophilia and related states).

(1964b). In “The Hemophilias", International " Symposium, Washington, ed. K. M. Brinkhous, pp. 359-362. Univ. of N. Carolina Press, Chapel Hill, N.C. (Psychiatric complications of hemophilia).

Britten, M. I., Spooner, R. J. D., Dormandy, K. M., and $\frac{\overline{\bar{c}}}{\mathrm{~s}}$ Biggs, R. (1966). Brit. med. J., 2, 224 (The haemophilic boy in school).

Browne, W. J., Mally, M. A., and Kane, R. P. (1960). ॐ Amer.J. Orthopsychiat., 30, 730 (Psychosocial aspects of $\vec{\circ}$ hemophilia: a study of 28 hemophilic children and their families).

Hollán, S. R., István, L., and Feszler, G. (1966). In $\stackrel{\text { S }}{\text { }}$ "Current Studies in Hemophilia", Proc. III Congr. $\bar{\nabla}$ Wld Fed. Hemophilia, Paris, 1965, ed. J. P. Soulier, 宁 pp. 153-155. Bibl. haemat., fasc. 26. Karger, Basel/New N York (Medical organization for hemophiliacs in N Hungary).

Katz, A. H. (1959). Soc. Casework, 40, 321 (Some psychosocial problems in hemophilia). (1963). Amer. J. publ. Hlth, 53, 1666 (Social adaptation in chronic illness: A study of hemophilia).

(1964. In "The Hemophilias", International Symposium, Washington, ed. K. M. Brinkhous, pp. $\vec{\bullet}$ 385-389. Univ. of N. Carolina Press, Chapel Hidj, N.C. (Social adaptation in hemophilia).

Poinsard, P. J. (1957). In "Hemophilia and Hemophilog Diseases", International Symposium, Washington, ef K. M. Brinkhous, pp. 249-253. Univ. of N. Carolina Press, Chapel Hill, N.C. (Psychiatric aspects hemophilia). 